\title{
On streams from glaciers
}

\section{Charles Knight F.L.S.}

To cite this article: Charles Knight F.L.S. (1876) On streams from glaciers, Philosophical Magazine Series 5, 1:6, 496-496, DOI: 10.1080/14786447608639072

To link to this article: http://dx.doi.org/10.1080/14786447608639072

$$
\text { 曲 Published online: } 13 \text { May } 2009 .
$$

Submit your article to this journal 전

LII Article views: 2

Q View related articles $\asymp$ 
ON STREAMS FROM GLACIERS. BY CHARLES KNIGHT, F.L.S.

To the Editors of the Philosophical Magazine and Journal,

Gantleman,

Wellington March 7, 1876.

In reference to Dr. Pfaff's experiments on the plasticity of ice, is the following extract from my Address to the Philosophical Society of Wellington of sufficient interest to appear among the Miscellaneous Articles of the Magazine?

"I see in Geikie's late work, 'The Great Ice Age,' that reference is made to the fact that, from the foot of glaciers in Greenland, streams of water issue and unite to form considerable rivers, one of which, after a course of forty miles, enters the sea with a mouth nearly three quarters of a mile in breadth.

"This flow of water, Geikie thinks, probably circulates to some extent below every glacier; and he accounts for it by the liquefaction of ice from the warmth of the underlying soil. A more complete explanation of this flow of water from glaciers estimated not less than 3000 feet thick will be found in the suggestion first made by Professor James Thomson, and subsequently proved by his brother Professor W. Thomson, that the freezing-point of water is lowered $0^{\circ} .23 \mathrm{Fahr}$. for each additional atmosphere of pressure. Now a sheet of ice 3000 feet thick is equal to the pressure of about 80 atmospheres, at which pressure its temperature at the base should not exceed $13^{\circ}$ Fahr. to retain the solid form. In the state of running water beneath the glacier, it might readily, as Geikie states, absorb heat from the underlying soil. In this we have a safe assurance that glaciers of such enormous thickness can exist only where there is scarcely any or no inclination of the land to the sea board. And we may hesitate to adopt with Geikie the views of the Swiss glacialists, who speak of sheets of ice having existed in the great Ice Age not less than 3000 feet thick, overtopping the Jura and stretching continuously from the Rhine valley.

"Sheets of ice 3000 or 5000 feet thick may exist, but not at the temperature of $32^{\circ}$ Fahr. throughout the whole mass. The temperature at the surface may be $32^{\circ}$ Fahr.; at the base it must be below $13^{\circ}$ Fahr. The specific heat of water is far greater than that of ice. One pound weight of ice at $32^{\circ} \mathrm{Fahr}$. mixed with one pound of boiling water gives 2 Ibs. of water at $51^{\circ}$ Fahr.; so that 71 degrees of heat are lost in the mere conversion of ice into water. Thus every pound of ice converted by pressure into water demands a large supply of caloric as a necessity of its change of condition, and absorbs it instantly from the ice above. The ice in immediate contact with the layer of water, hardened by loss of caloric, now robs the ice above of caloric, and again softened can no longer bear the pressure, and in its turn flows away as water; and so the process goes on, until a regular gradation of temperature is established throughout the mass, and an equilibrium formed between the forces by which the sheet of ice maintains a fixed altitude. No column of ice 3000 feet in height can maintain that elevation for an indefinite time, unless the temperature of the air is much lower than $32^{\circ} \mathrm{Fahr}$., and the loss from liquidation beneath constantly supplemented by renewed accumulations abore." 